\title{
Tomato brown rugose fruit virus (ToBRFV): Güncel durumu ve geleceği
}

\section{Tomato brown rugose fruit virus (ToBRFV): Current situation and future prospects}

\author{
Hakan FİDAN \\ Akdeniz Üniversitesi, Ziraat Fakültesi, Bitki Koruma Bölümü, Antalya \\ Sorumlu yazar (Corresponding author): H. Fidan, e-posta (e-mail): hakanfidan@akdeniz.edu.tr
}

MAKALE BİLGİİ

Alınıs tarihi 18 Mart 2020

Düzeltilme tarihi 20 Mart 2020

Kabul tarihi 23 Mart 2020

\section{Anahtar Kelimeler:}

Tobamovirus

Tomato brown rugose fruit virus

Domates

Biber

Dayanıklılığın kırılması

\begin{abstract}
öz
Tobamovirus cinsinde Tomato brown rugose fruit virus (ToBRFV) olarak tanımlanan yeni bir virüs geniş yayılım alanlarında epidemi yapmıştır. ToBRFV, ilk olarak 2014 yılında İsrail'de tespit edilmiştir. O zamandan günümüze kadar virüs Avrupa, Kuzey Amerika, Asya, Türkiye ve daha birçok ülkede tespit edilmiştir. ToBRFV, bitkisel üretimi, domates ve biberlerin pazarlanabilirliğini önemli ölçüde etkileme potansiyeline sahiptir. Virüs bir gıda güvenliği riski değildir. $\mathrm{Bu}$ virüs esas olarak domates ve biberleri etkilemektedir. Solanum nigrum gibi bazı yabancı ot türlerinin virüse konukçuluk yapabildiği belirlenmiştir. ToBRFV hastalığı da diğer Tobamovirus'ler gibi tohumla ve mekaniksel temas ile işçilerin elleri, kıyafetleri, bombus arıları, sera alet ekipmanları yoluyla çok etkili bir şekilde taşınabilmektedir. ToBRFV, Tobamovirus'lere dayanıklılık sağlayan domateslerdeki Tm $2^{2}$ genini ve biberlerdeki L1, L2, L3 genlerini etkisiz kılarak enfeksiyon yapmaktadır. Bugüne kadar ToBRFV, ağırlıklı olarak sera domateslerinde rapor edilmiştir. Domates meyvelerinde buruşuk kahverengi veya sar lekeler göstermektedir. Bu belirtiler, meyvelerin piyasa değerini önemli ölçüde azaltmaktadır. Virüsün seralara girișini ve yayılmasını sınırlamak için katı biyogüvenlik önlemleri gereklidir. Üreticiler, güvenilir kaynaklardan tohum ve fide kullandıklarından emin olmalıdır.
\end{abstract}

\section{ARTICLE INFO}

Received 18 March 2020

Received in revised form 20 March 2020

Accepted 23 March 2020

\section{Keywords:}

Tobamovirus

Tomato brown rugose fruit virus

Tomato

Pepper

Resistance breaking

\begin{abstract}
A new virus, defined as Tomato brown rugose fruit virus (ToBRFV) in the genus Tobamovirus, has made the epidemic in wide spread areas. ToBRFV was first detected in Israel in 2014. Since then, the virus has been detected in Europe, North America, Asia, Turkey and many more countries. ToBRFV has the potential to significantly affect crop production, the marketability of tomatoes and peppers. The virus is not a food safety risk. This virus mainly affects tomatoes and peppers. It has been determined that some weed species, such as Solanum nigrum, can host the virus. Like other Tobamoviruses, ToBRFV can be transported very effectively with the hands and clothes, bumblebees, greenhouse tool equipment, with seeds and mechanical contact. ToBRFV infects by neutralizing the Tm $2^{2}$ gene in tomatoes and L1, L2, L3 genes in peppers, which provide resistance to Tobamoviruses. To date, ToBRFV has been reported mainly in greenhouse tomatoes. It shows brown rugose or yellow spots on tomato fruits. These fruit symptoms significantly reduce market value. Strict biosafety measures are required to limit the entry and spread of this virus into greenhouses. Producers should make sure they use seeds and seedlings from reliable sources.
\end{abstract}

\section{Giriş}

Solanaceae familyasındaki domates (Solanum lycopersicum), 2007 ve 2017 yılları arasinda 45 milyon tonun üzerinde artan küresel bir üretim ile en önemli ve yaygın olarak yetiştirilen ürünlerden biri haline gelmiştir (FAO 2017). Domateste patojen enfeksiyonlarını önleme çabalarına rağmen, viral hastalıkların kontrolü oldukça zordur. Mücadele stratejileri, mevcut virüslerin yeni ırklarının veya tamamen yeni virüslerin sürekli ortaya çıkmasıyla giderek zorlaşmaktadır. Virüsler, geniş popülasyonları, genetik varyasyonu kolaylaştıran tamir mekanizmalarının genomlarında olmaması ve kısa sürede çoğalabilmeleri gibi nedenlerle doğal seleksiyon baskısına uyum sağlama konusunda büyük bir potansiyele sahiptir (Hanssen ve ark. 2010). Viral genomlarda yüksek mutasyon ve rekombinasyon yeteneği, popülasyonda hızla yayılan yeni varyantların üretimini arttırmaktadır (Moya ve ark. 2004). Viral hastalıklardan etkilenen domates bitkilerinin besin içeriği, meyve kalitesi ve verimi azalarak raf ömrü kısalmaktadır (Hanson ve ark. 2016). 
Tarla veya sera bitkilerinde sorunlara neden olmaya devam eden birçok farklı virüs hastalığ zamanlarda Tobamovirus cinsinde Tomato brown rugose fruit virus (ToBRFV) olarak tanımlanan, seralar ve üretim sahalarında yeni ortaya çıkan ve geniş yayılım gösteren bir viral patojen dünya çapında büyük önem kazanmıştır.

Örtü altı veya tarla koşullarında yetiştirilen domates bitkileri özellikle mekanik ve tohumla bulaşan virüs cinsi Tobamovirus'ler nedeniyle enfeksiyonlara yüksek derecede maruz kalmaktadırlar. Uluslararası Virüs Taksonomisi Komitesi'nin (International Committee on Taxonomy of Viruses-ICTV) 2015 sürümüne göre Tobamovirus cinsinin Virgaviridae ailesindeki yedi cins arasında 35 türe sahip olan en büyük cins olduğu belirtilmiştir. Tobamovirus cinsi de iyi bilinen türler arasında Tobacco mosaic virus (TMV) (Mayer ve ark. 1942), Tomato mosaic virus (ToMV), Pepper mild mottle virus (PMMoV), Tobacco mild green mosaic virus (TMGMV) Solanaceae familyasındaki ürünleri enfekte edebilmektedirler (Adams ve ark. 2009; King ve ark. 2012). Paprika mild mottle virus (PaMMV) (Hamada ve ark. 2003), Bell pepper mottle virus (BPeMV) (Wetter ve ark. 1987), Cucumber green mottle mosaic virus (CGMMV) (Liang ve ark. 2019) ve Odontoglossum ringspot virus (ORSV) (Pai ve ark. 2019) türleri de Tobamovirus cinsinde yer almaktadırlar. Tobamovirus'ler mekanik temasla bulaşmaktadır: İşçilerin elleri, kıyafetleri, bombus arıları, sera alet ekipmanları yoluyla taşınarak tohumlardaki ve kontamine topraklardaki enfektivitesini koruyabilmektedir (Luria ve ark. 2017). Domateslerde sırasiyla Tm-2 ve $T m-2^{2} \mathrm{R}$ (Resistance) genleri tarafindan TMV ve ToMV'ye dayanıklılık sağlandığı bilinmektedir. Tm-2 ve Tm- $2^{2}$ dayanıklılık genleri, viral hareket proteinini avirulens protein (Avr) olarak paylaşmaktadır. Tm- $2^{2}$ geninin, direnci kırılan Tm2 'den daha dayanıklı olduğu bilinmektedir. Bununla birlikte, domatesleri enfekte eden yeni Tobamovirus'ler tanımlandığından Tm-2 ${ }^{2}$ direncinin etkinliği tartışılmaktadır: Meksika'da Tomato mottle mosaic virus (ToMMV) ve Ürdün'de ToBRFV olarak adlandırılan Tobamovirus'lerin bu dayanıklılık geninin üstesinden geldiği bildirilmiştir. ToMMV, domates fidelerinin yapraklarında doku nekrozuna; olgun bitkilerde mozaik ve yaprak bozulmasına neden olmaktadır. Ülkemizde varlığı ile ilgili bir kayıt bulunmamaktadır.

\section{Domates Üretiminde ToBRFV'nin Ortaya Çıkışı ve Simptomları}

Bugüne kadar, ToBRFV enfeksiyonu Ürdün (Salem ve ark. 2016), İsrail (Luria ve ark. 2017; Alkowni ve ark. 2019; Levitzky ve ark. 2019), Meksika (Cambron-Crisantos ve ark. 2018, Camacho-Beltrán ve ark. 2019; Ling ve ark. 2019), ABD (Chitambar 2018; Ling ve ark. 2019), Almanya (Menzel ve ark. 2019), İtalya (Panno ve ark. 2019), Filistin (Alkowni ve ark. 2019), Türkiye (Fidan ve ark. 2019), Çin (Yan ve ark. 2019) ve İngiltere (Skelton ve ark. 2019)'den rapor edilmiştir. Belçika, Yunanistan, Hollanda, İspanya gibi ülkelerde de ToBRFV enfeksiyonu kayıt edilmiştir (EPPO 2020). Şili, Etiyopya ve Sudan'da da meydana geldiği bildirilmiş ancak doğrulanmamıştır. Salem ve ark. (2016), ilk defa 2015 yılında Ürdün'den domates mahsullerinde ToBRFV salgının1 bildirilmiştir. Bununla birlikte, şu anda bulunduğu ülkelerde ToBRFV hastalığının simptomlarının iyi anlaşılması ya da tanılama çalışmalarında ToBRFV için spesifik bir yöntemin kullanılması büyük önem taşımaktadır.

Maayan ve ark. (2018) farklı Tobamovirus'lerin kapsamlı bir filogenetik analiz ve genomik karşılaştırması ile ilgili yaptıkları çalışmada ToBRFV varyantındaki konukçu kayması olayının çok kısa bir sürede düşük bir mutasyon oranıyla meydana geldiği sonucuna varmıştır. ToBRFV'nin rekombinasyon sonucu ortaya çıkmış olabileceği düşünülmektedir. Bu sebeple potansiyel küçük ebeveyn olarak ToMMV ve büyük ebeveyn olarak TMV'nin Ohio V suşunu tanımlayan bir rekombinasyonu tanımlamak için algoritmalar kullanılmıştır (Salem ve ark. 2016). Ayrıca; yetiştirilen domates çeşitleri, tohum kaynağı, alternatif konukçular veya kullanılan yetiştirme sisteminin ortak bağlantıları da olabileceği belirtilmiștir. Solanum nigrum, Chenopodium murale ve Petunia hybrida gibi birkaç yaygın yabancı ot, İsrail'de virüsün potansiyel kaynakları olarak tanımlanmıştır (Luria ve ark. 2017). Bu yabancı otların ülkemizde de bulunduğu ve aynı potansiyele sahip olduğu unutulmamalıdır. Bununla birlikte, Kuzey Filistin'de tarımsal ürün yetiştiriciliğinde virüsün kolaylıkla çoğalabildiği ve şiddetli enfeksiyon yapabildiği domates bitkileri tercih edildiği için ToBRFV'nin yayılması devam etmektedir (Alkowni ve ark. 2019).

Domates (Solanum lycopersicum) ve biber (Capsicum sp.) ToBRFV'nin ana konukçusudur (Cambrón-Crisantos ve ark. 2018). Luria ve ark. (2017) yaptıkları konukçu aralığı belirleme çalışmalarında mekanik inokulasyon çalışmalarıyla patates (Solanum tuberosum cv Nicola) ve patlican (Solanum melongena cv Classic, cv 206) bitkilerine ToBRFV inokule etmişler ve bu ürünlerin enfekte olmadığını belirlemişlerdir. Petunya (Petunia hybrida) bitkisinin ise simptomsuz konukçu olduğu bildirilmiştir. İnokule edilen tütün türlerinden Nicotiana benthamiana, $N$. glutinosa ve $N$. sylvestris'de inokulasyondan 7-14 gün sonra çökme görülmüştür. Yabanc1 ot türlerinden Solanum nigrum ve Chenopodium murale etmen için konukçu oldukları belirlenmiştir (Tarım ve Orman Bakanlığı 2019).

Tomato brown rugose fruit virus (ToBRFV)'ü diğer Tobamovirus'lerden ayıran bazı belirtiler gözlemlenmiştir. Domatesteki simptomları iki tipte sınıflandırmak mümkündür; bazı çeşitlerin yapraklarında şiddetli mozaik simptomlarıyla gösterebilirken, bazı çeşitlerde meyve oluşuncaya kadar yaprak simptomu göstermemekte ve bu virüsün varlığı ancak meyvedeki simptomlar ile fark edilebilmektedir. Domates yapraklarında klorotik mozaikler, buruşma ve deformasyonlar; $\mathrm{Tm} 2^{2}$ dayanımı olan çeşitlerde meyvede düzensiz sarı halkalar meydana gelirken; dayanımı olmayan çeşitlerde kahverengi buruşuk (rugose) lekeler oluşmaktadır. (Şekil 1). ToBRFV tohumla taşınsa dahi bazı çeşitlerde meyve oluşup renk değişimi oluncaya kadar yaprak simptomu vermemektedir (Fidan ve Sarıkaya 2020a). Bazı çeşitlerde ise iklim koşullarının müsait olması durumunda ilk bir ay içerisinde simptomlar gözlemlenmektedir. $\mathrm{Bu}$ durumun, çeşidin sslah geçmişi ile (background) ilgili olduğu düşünülmektedir. Bu özellik dikkate alınarak dayanıklılık çalışmalarında meyvelerde renk oluşumuna kadar simptom gözlenmesi yapılması gerekmektedir.

Tm-2 $2^{2}$ dayanımı olmayan çeşitlerde yapraklarda mozaik, kabalaşma sarı kahverengi nekrotik lekeler meyvede nekrotik alanlar şeklinde kendini göstermektedir. Tm- $2^{2}$ dayanımı olan beef (iri domates) çeşitlerde ise yapraklarda iplikleşme ve uzama şeklinde simptom göstermektedir. Simptomlar Cucumber mosaic virus (CMV ve/veya Potato virus Y (PVY) simptomlarına çok benzemektedir (Şekil 2).

Tobamovirus'lere karşı biberde dayanıklılık sağlayan L genlerine sahip biber bitkilerinde yapılan mekanik inokulasyonlar sonucunda L4 genine sahip biberlerde HR (Hipersensitif Reaksiyon) geliştiği ve bitkilerin etkilenmediği gözlense de yüksek sicaklık ( $32^{\circ} \mathrm{C}$ 'nin üzerinde) ve üst üste 

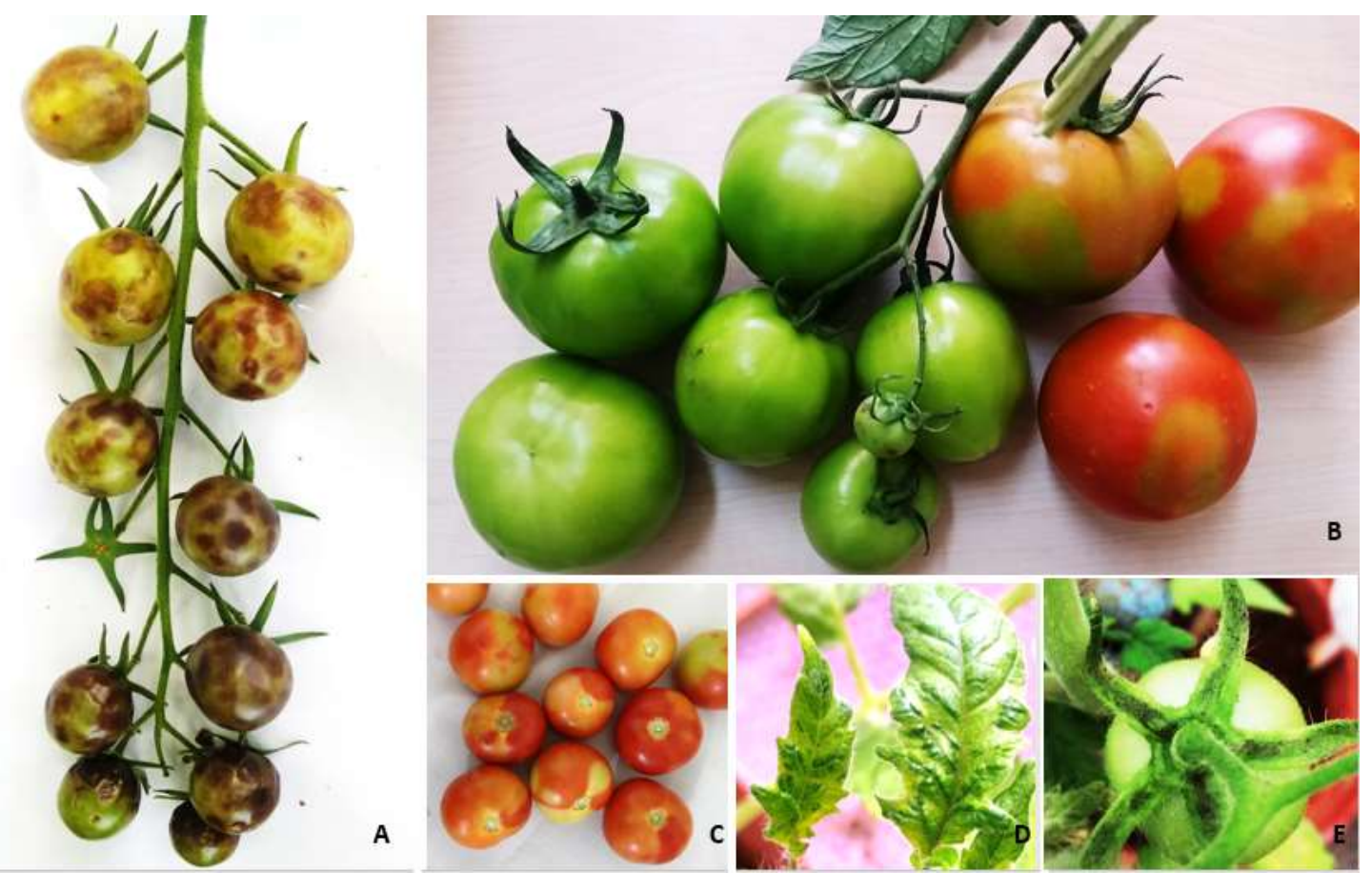

Şekil 1. A: Hassas çeşitlerde gözlenen kahverengi buruşuk (rugose) leke simptomları; B, C: Tm2² dayanımı olan çeșitlerin meyvelerinde görülen düzensiz sarı halka simptomları; D: Tm2 2 dayanımı olan çeşitlerin yapraklarında görülen şiddetli mozaik simptomu; E: Kalikste meydana gelen kahverengileşme simptomu.

Figure 1. A: Brown rugose symptoms in susceptible varieties; B, C: Irregular yellow ring symptoms in the fruits of $\operatorname{Tm}^{2}$ resistant varieties; D: Severe mosaic symptom in the leaves of $\mathrm{Tm} 2^{2}$ resistant varieties; E: Browning symptom in calyx.
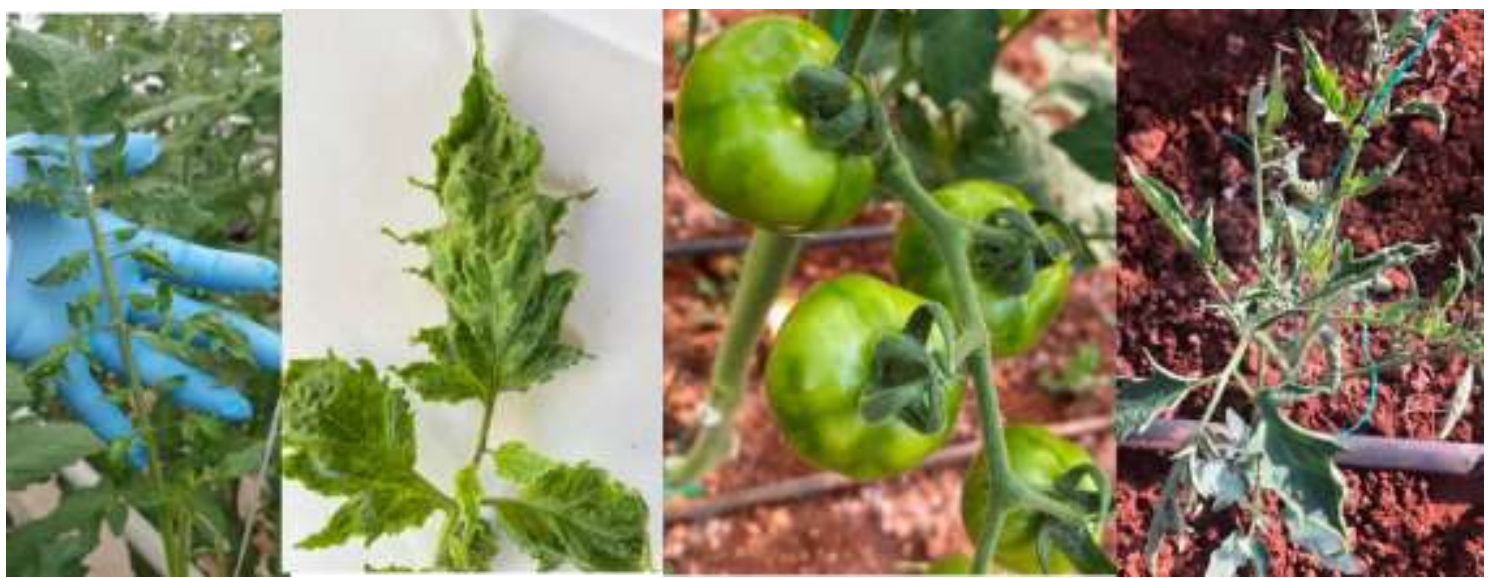

Şekil 2. Domates bitkilerinde CMV ve PVY benzeri simptom gösteren örnekler.

Figure 2. Samples showing CMV and PVY-like simptom on tomato plants.

enfeksiyona maruz kalma (bulaşma) durumlarında L4 genine sahip biberlerde de kahverengi akıntı, renk bozukluğu, meyvede kırılgan ve gevrek yapı; sıcaklığın artmasına bağlı yapraklarda mozaik, kıvrılma ve kabalaşma gözlemlenmektedir. Bu sebeple biber bitkilerinde de meyvedeki renk dönümüne kadar bitkilerin kontrol edilerek simptomların gözlenmesi gerekmektedir. Diğer L genlerine sahip biberlerin (L1, L2, L3) hassas olduklar1 gözlemlenmiştir. Dolmalık ve kapya biberlerin daha hassas olduğu, meyve içindeki tohumlara bakıldığında Tobamovirus'lerde s1k rastlanan tohum etrafinda kahverengi klorotik halkalar ve gövdede siyahlaşmalar gözlemlenmektedir (Şekil 3). ToBRFV'nin domates ve biber bitkilerinde meyvelerde renk dönümü gözleninceye kadar simptom vermemesi, virüsün tespitini zorlaştırmakta ve önlem almakta geç kalındığı için önemli derecede ekonomik kayıplara sebep olmaktadır.

\section{ToBRFV'nin Moleküler Özellikleri ve Tanılanması}

ToBRFV'nin genom organizasyonu, Virgaviridae ailesinin en büyüğü olan Tobamovirus cinsinin tipik özellikleriyle tanımlanmıştır ve bu nedenle TMV, ToMV, ToMMV, CGMMV ve ORSV ile ilgili olduğu düşünülmektedir (Adams ve ark. 2009, 2012). Tobamovirus'ler, dört ORF (Open reading frame)'yi kodlayan 6.2 ila $6.4 \mathrm{~kb}$ tek sarmallı RNA (+ssRNA) genomunu kapsayan tipik bir çubuk şekilli parçacık morfolojisi ile karakterize edilmektedir (Şekil 4). ORF1 ve ORF2 bir stop kodonu ile ayrılmakta ve replikaz kompleksini oluşturan yapısal 


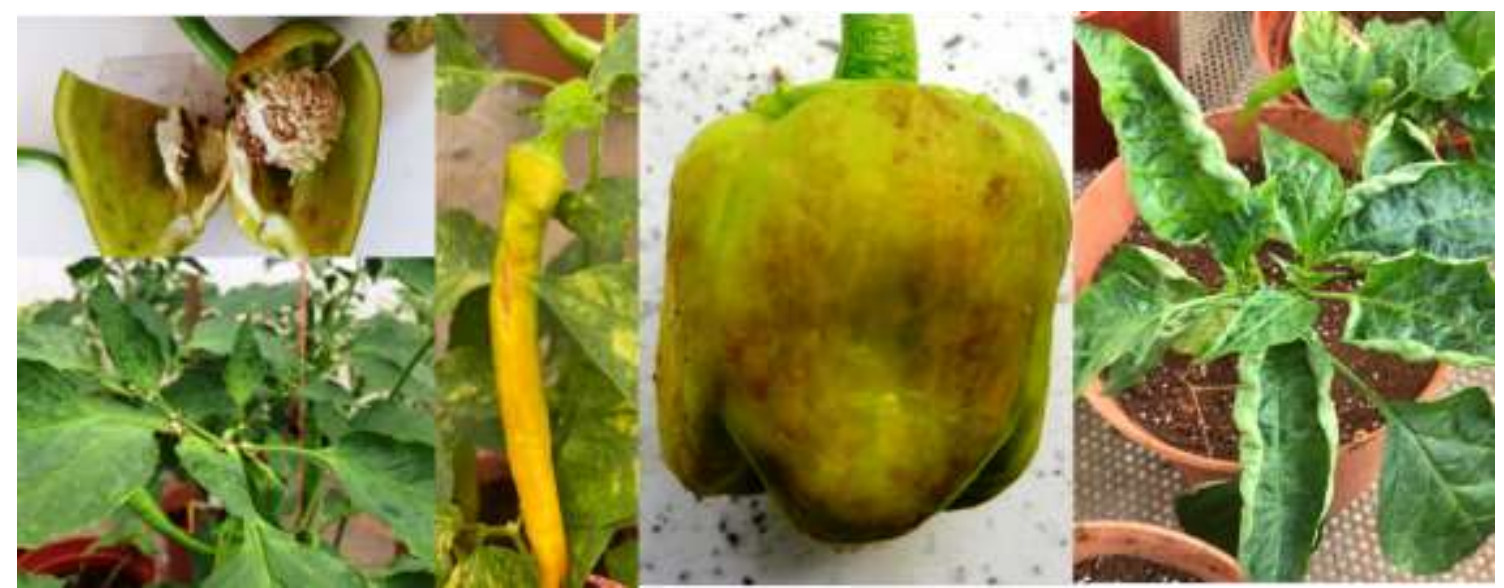

Şekil 3. Biber bitkilerinde enfekteli tohum ve meyvelerde kahverengileşme belirtileri.

Figure 3. Infected seeds in pepper plants and browning symptoms in fruits.

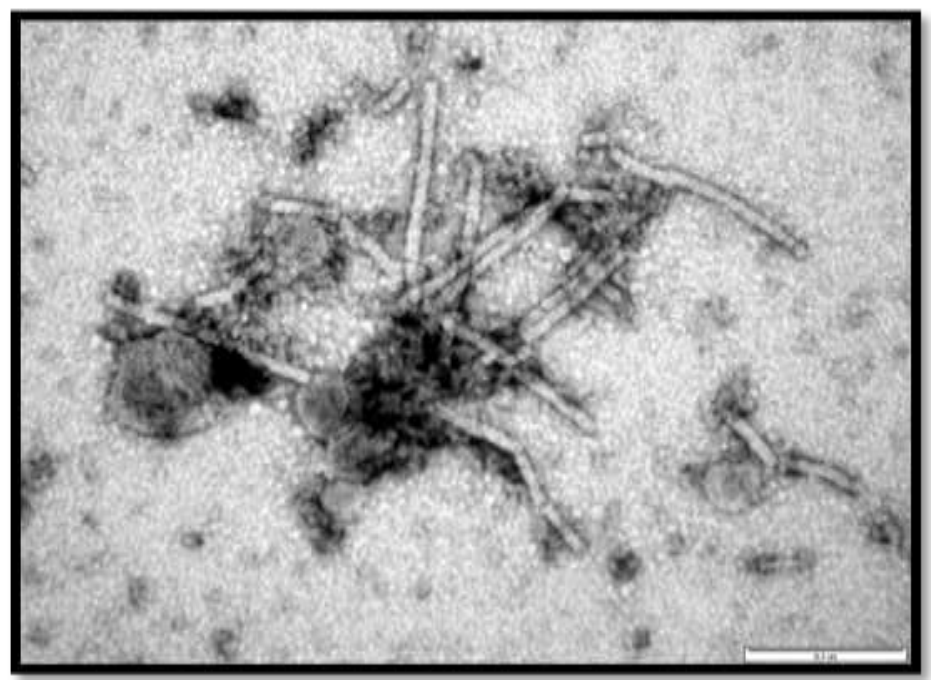

Şekil 4. MT107885 TBRFV-Ant-Tom NCBI kayıtlı Antalya domates ToBRFV izololatının Zeiss Leo 906 E TEM (Germany) Elektron mikroskobu görüntüsü.

Figure 4. Zeiss Leo 906 E TEM (Germany) Electron microscope image of Antalya tomato ToBRFV isolate registered in NCBI with MT107885 genbank numbered and TBRFV-Ant-Tom named.

olmayan proteinleri kodlamaktadır. Büyük subgenomik RNA üzerindeki ORF3, yapısal olmayan hareket proteinini (Movement protein-MP) kodlamaktadır. Küçük subgenomik RNA üzerindeki ORF4, 17 ila 18 kDa'lık kılıf proteinini (Coat protein-CP) kodlamaktadır. Bu cinsteki diğer virüsler gibi, genomik analiz de tipik bir izolatın yaklaşı $6.4 \mathrm{~kb}$ nükleotitlik uzunlukta bir genomu olduğunu ve izolatların genetik olarak birbiriyle yakından ilişkili olduğunu ortaya koymuştur. $\mathrm{Bu}$, enfekte olmuş bölgelerden sekanslanan izolatların aynı ToBRFV soyundan geldiği anlamına gelmektedir. Bu amaçla Antalya'da domates ve biberde tespit edilen ToBRFV izolatlarının tüm genomu çıkarılmıștır. NCBI (The National Center for Biotechnology Information) veritabanına MT107885 TBRFV-Ant-Tom domates izolatı (6386 nükleotit) ve MT118666 TBRFV-Ant-Pep (6373 nükleotit) biber izolat1 olarak kayıt edilmiştir. Dayanıklılık kırılmasına sebep olan genomik dizilim, örneğin ToMMV ve TMV veya ToMV arasında, Tobamovirus RNA genomunun değişkenliğinden kaynaklanmış olabilecek karşılaştırmalar yaparken, bilinen virüslerden \%9-15 oranında farklılık gösterebileceğini göstermiştir. (Domingo ve Holland 1997). Aksine filogenik analiz, ToBRFV'nin genomik sekansının ToMV veya TMV'den \%18 oranında farklılık gösterdiğini ve ToMV ve TMV'nin ortak bir atalarından kaynaklanabileceğini düşündürmektedir (Maayan ve ark. 2018).

Tobamovirus üyesi ToBRFV'yi, diğer Tobamovirus'lerden ayırt edecek tanılama kitlerinin (DAS-ELISA vb.) geliştirilmesinde geç kalınması ya da bu tanılama kitlerinin spesifikliği ve etkinliğindeki sıkıntılar bu virüs hastalığının hızlı bir şekilde yayılmasına neden olmuştur. Bu amaçla 2019 yılında T.C. Tarım ve Orman Bakanlığı Zirai Karantina Müdürlüğüne, Akdeniz Üniversitesi Ziraat Fakültesi Moleküler Viroloji Laboratuvarlarında ToBRFV'yi, diğer Tobamovirus'lerden ayırt ederek tanılama yapan RT-PCR ve Real-Time RT-PCR primer ve probları (Fidan 2019) geliştirilmiştir. Bu tanılama kitleri teşhis çalışmalarında başarıyla kullanılmaya devam etmektedir.

\section{Uygulanabilir Kontrol Stratejileri}

Tobamovirus'ler, özellikle Solanaceae ve Cucurbitaceae familyalarına ait birçok ürün için ciddi bir sorun oluşturmaktadır. Hem tohum kaynaklı hem de mekanik olarak 
bulaşan bitki virüsleri olmaları sebebiyle bitkisel ürünlerdeki patojenin taşınması ve ülkeler arasındaki bitkisel alışverişte virüs hastalıkları açısından test edilmeyen enfekteli tohumlar ile yayılması kaçınılmazdır.

Tobamovirus'ler enfekte olmuş tohum kabuklarına temas eden kotiledonların mekanik aşılanmasıyla da sıklıkla bulaşmaktadır. Serada var olan virüsün, bombus arılarının, kullanılan alet ve ekipmanların, giysilerin, kasaların ve enfekteli bitkilere bağlanmış iplerin tekrar kullanılması ile hızlı bir şekilde dağılacağı unutulmamalıdır (Oladokun ve ark. 2019; Fidan ve Sarıkaya 2020a).

$\mathrm{AB}$ içindeki ülkeler, ticari ürünlerin genel tohum sağllğı testi de dahil olmak üzere, bitki zararlıları risk değerlendirmesi ve analizine dayalı olarak ortaya çıkan herhangi bir bitki virüs için bitki sağlı̆̆ önlemleri ve kontrol stratejilerine sahiptir. Ancak gelişmekte olan ülkeler, bitki sağlığı çerçevesinin uygulamaya konulması bakımından farklı bir durumdadır. Mekanik olarak taşınan ToBRFV için şu anda dayanıklı çeşitler mevcut olmadığından, kontrol önlemleri için başlangıçta hijyen önlemlerine odaklanılmalıdır. Hastalığın ekonomik etkisi ile ilgili olarak ToBRFV'nin domates bitkilerinde bulunan iki dayanıklılık genlerini etkisiz kıldığı bilinmektedir. Benzer şekilde, belirli koşullar altında L1, L2 ve L3 olmak üzere L direnç genlerini barındıran biber bitkileri de tehlikeye girmiştir (Luria ve ark. 2017). Yapılan biyolojik indeksleme çalışmaları ile L4 genini bulunduran biber çeşitlerinde ToBRFV'ye karşı dayanıklılığın korunduğu ve bitkilerde HR belirtileri meydana geldiği belirlenmiştir (Şekil 5). Tohumların bulaşık olması ve bunu takiben üst üste enfeksiyonların olmasıyla birlikte uygun çevre koşullarında L4 genine sahip çeşitlerde de ToBRFV simptomları gözlemleneceği unutulmamalıdır.
Seralar ve korunan alanlarda çoğunlukla ekim nöbeti olmaması ve monokültür ürünlerin yetiştirilmesi, Tobamovirus enfeksiyonlarının yayılmasına olanak sağlamaktadır (Dombrovsky ve Smith 2017). Böylece enfekteli domates ve biber meyvelerinin verimliliği ve kalitesi etkilenmekte, meyvenin piyasa değeri düşmekte, hastalı̆̆ı önleme çalışmalarıyla birlikte üretim maliyetleri artmakta ve dolaylı olarak çoğu yetiştiricinin kültürel uygulamaları değişmektedir. $\mathrm{Bu}$ nedenle sürdürülebilir bir yönetim uygulama girişimlerinde sonuçların ekonomik etki açısından dikkatli bir şekilde incelenmesi çok önemlidir. Ayrıca, yüksek enfeksiyonu olan bölgelerde viral popülasyonun aynı olması koşuluyla çapraz koruma stratejileri geliştirilebilmektedir (Lecoq 1998; Gal-On ve Shiboleth 2006).

Stratejilere ek olarak, yerel düzeyde açık alan sistemleri uygulayan yetiştiriciler ekim ve budama sisteminin değiştirilmesi, alternatif konukçu bitkilerin ortadan kaldırılması, hasat ve ayıklamadan sonra kalan bitki artıklarının giderilmesi, yabancı otların kontrol edilmesi gibi kültürel uygulamalar kullanılması gerekmektedir. Kültürel mücadele yolları hastalık yayılmasını önleme girişiminde önemli bir rol oynamaktadır. $\mathrm{Bu}$ faaliyetler virüsün yayılmasını sınırlandırmaya yardımcı olacaktır ve ana ürün üzerindeki beslenme tercihini değiştirebilmektedir. Bitki virüs hastalıklarının gelecekteki kontrol stratejileri için Prins ve ark. (2008), viral sekanslardan türetilen ve viral gen ekspresyonunun gen susturulmasını tetikleyebilen transgeninin bitki genomuna sokulmasının ümit verici bir strateji olduğunu bildirmişlerdir.
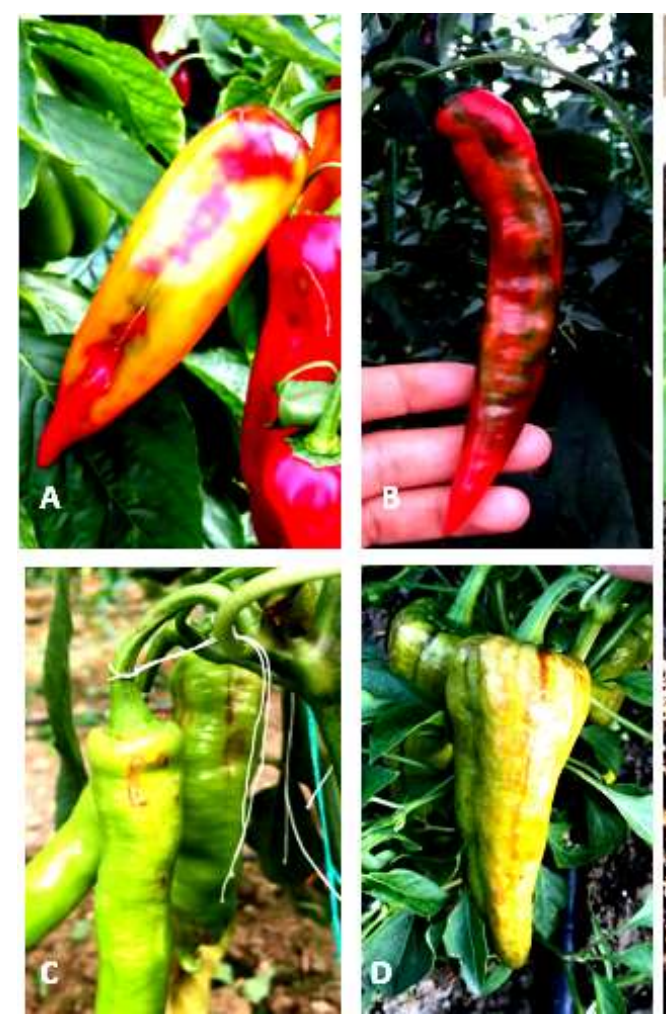

Şekil 5. A, B, C, D: L1, L2, L3 genlerini birlikte bulunduran biber çeşitlerindeki meyve simptomlar1; E: L4 geni bulunduran biberdeki HR simptomu.

Figure 5. A, B, C, D: Fruit symptoms in pepper varieties harboring L1, L2, L3 genes together; E: HR symptom in pepper with L4 gene. 
Virüs hastalıklarına karşı dayanıklı veya toleranslı çeşitlerin kullanılan marker yardımlı seçilim (MAS-Marker Asisted Selection) yönteminin, ToBRFV hastalığına karşı dayanıklılığının geliştirilmesi için kullanımı tavsiye edilmektedir. Ayrıca, test edilmiş temiz tohum kullanıldığında, dikimden önce uygun toprak sterilizasyonu yapıldığında ve bitkilerin bir yerden başka bir yere taşınmasında gereken hijyen kurallarına uyarak önlem alındığında; enfeksiyon görüldüğü durumlarda sera yetiştiriciliği yapan ülkeler virüs partikülünü taşıyan bitkileri zamanında tespit ederek imha etmesiyle bu viral tehdidin üstesinden gelebilirler.

\section{Gelecekteki Yaklaşımlar}

Diğer bitki virüsleri gibi ToBRFV epidemiyolojisinin de önleyici kaynaklarını bilmek ve anlamak etkili kontrol stratejileri bulma çabalarında kritik bir husustur. Her ne kadar viral inokulasyonların kaynağı olarak mekanik bulaşma yollarına işaret etse de diğer potansiyel bulaşma yolları göz ardı edilmemelidir.

Domates ve biber bitkilerinin yetiştirildiği her yerde iklim ve konukçu arasındaki etkileşimin, ToBRFV'nin daha geniş yayılmasında önemli bir rol oynaması muhtemeldir. Bu nedenle Solanaceae familyasına ait bitkileri yetiştiren ülkelerde bulunan ve hastalığın oluşumuna katkıda bulunabilecek uygun alternatif konukçuları ve iklim koşullarını değerlendirmeleri gerekmektedir. Özellikle enfeksiyondan etkilenen ülkelerdeki, komşu ülkelerdeki veya risk altındaki bölgelerdeki hastalığın ilerlemesini takip edebilmek için başlıca domates ve biber üreten bölgelerde ToBRFV oranının düzenli olarak izlenmesi gerekmektedir. Bunu desteklemek için yetiştiricilerin farkındalığı ToBRFV'nin etkili kontrol yönetiminin formüle edilmesinde yardımcı olacaktır (Oladokun ve ark. 2019).

Virüsün düzenli olarak gözetimi, salgınların raporlanmas1, bilgi ve diğer kaynakların ortak paylaşımı ve bitki sağlı̆̆ hizmetlerinin faaliyetleri için geniş çaplı taramalar ciddiye alınmalı ve sürdürülmelidir. İletim için birincil yolun mekanik yollarla taşınan özsu olduğu bilinmektedir. Bombus arıları, doğal yollarla enfekte olmuş tohumlardan veya fidelerden sağlıklı bitkilere mekanik olarak taşınan virüs partiküllerini bulaştırma riski taşımaktadır. Daha geniş yayılımı önlemek için tarladaki böceklerin düzenli kontrolleri mutlaka yapılmalıdır (Dombrovsky ve Smith 2017).

Uygun yönetim, hastalık yayılımı ile ilişkili bitki büyümesinin tüm yönlerini kapsamalıdır. Enfekte olmuş topraklarda önceki patojenlerin kalıntılarının ve serada kullanılan iplerin dezenfeksiyonu, sera yapılarının biyogüvenlik önlemleri; işçilerin ellerine bulaşma riskinin önlenmesi, giysi ve ayakkabı değişimi oldukça önemlidir. Bu koşullar dikkate alındığında, başka bir yerde ToBRFV hastalığının ortaya çıkma olasıllkları sınırlı olacak ve önemli ölçüde kontrol edilecektir.

Tek bir kontrol yöntemiyle herhangi bir bitki hastalığ1 problemi çözülemez (Oladokun 2019). Uygun teşhis yöntemlerinin kullanımı ile birlikte mevcut tüm teknolojileri kullanarak entegre bir yönetim sistemi aracılığıyla verim kayıplarının en aza indirilmesi gerekmektedir. Domates ve biberdeki dayanıklılık genlerini zayıf hale getiren yıkıcı ToBRFV hastalığının ortaya çıkması hızlıca çözüme ulaşılmasını gerektirmektedir. $\mathrm{Bu}$ nedenle ürün çeşitlerine dayanıklılık kazandırmak için yeni yolların araştırılması gerekmektedir. MAS çalışmaları ve CRISPR-Cas9 gibi gen düzenleme araçlarının kullanılması yoluyla dayanıklılık genlerinin bir türden diğerine aktarılması, geleneksel yetiştirme programına şimdi ve yakın gelecekte alternatif bir yaklaşım sağlayacaktır (Fidan ve Sarıkaya 2020b).

\section{ToBRFV Yayılımını Sınırlamaya Yönelik Öneriler}

- Başlangıç materyalinin temiz olması, sertifikalı ve güvenilir laboratuvarlardan tohum ve fidelerin virüsten ari olduğu raporunun alınması mücadelede en önemli kriterdir.

- Üretim yapılan alanlara yalnızca temiz giysilerle girilmelidir. Tercihen kullanımdan sonra serada kalacak koruyucu giysiler kullanılmalıdır. İş ayakkabıları seraya girmeden önce ve seradan ayrildıktan sonra dezenfektanla temizlenmelidir.

- Bitkilere dokunmadan önce ve sonra eller, sabun veya dezenfektanla yıkanmalı, iyi hijyen uygulamaları takip edilmelidir. Gerekli değilse bitkilere kesinlikle temas edilmemelidir. Dezenfektan ile her bitkiden sonra kesici aletler ve seradaki diğer aletler sterilize edilmelidir. Bir ürün mevsiminin sonunda sera iyice temizlenmeli ve dezenfekte edilmelidir.

- Enfekteli bir bitki tespit edilirse emin olmak için uzman bir laboratuvar tarafından yapılacak teşhisin onayı alınmalıdır. Simptomatik bitkiler dikkatlice çıkarılmalı, gömmek veya yakmak suretiyle yok edilmelidir. Enfekte olmuş her seraya ayrı bir birim olarak muamele edilmeli; laboratuvar önlüğü, eldiven ve steril aletler kullanılmalı ve bunlar serada saklanmalıdır. Enfekte olmuş bitkilerin bulunduğu alanı çevreleyen alan, serada yayılmayı önlemek için en son çalışılmalıdır. Enfekte olmuş bir seradan veya tarladan enfekte olmayan bir seraya giriş yapmaktan kaçınılmalı, günlük işlemler seraların hijyen durumuna göre ayarlanmalıdır. Ekim sonunda tüm malzemelerin ve seraların temizlendiğinden ve dezenfekte edildiğinden emin olunması tavsiye edilmektedir.

- Sera alet ekipmanlarının (metal aksam, naylon, kasa, toprak vb.) dezenfektan ile sterilize edilip üretime başlanması ve virüs enfeksiyonu olup olmamasına bakılmaksızın her sezonda bu önlemlerin tekrarlanması alışkanlık haline getirilmelidir.

\section{Kaynaklar}

Adams MJ, Antoniw JF, Kreuze J (2009) Virgaviridae: A new family of rod-shaped plant viruses. Archives of Virology 154 (12): 1967-72. doi: 10.1007/s00705-009-0506-6 PMID: 19862474.

Adams MJ, Heinze C, Jackson AO, Kreuze JF, Macfarlane SA, Torrance L (2012) Family virgaviridae. In: King AMQ, Adams MJ, Carstens EB, Lefkowitz EJ, eds. Virus Taxonomy - Ninth Report of the International Committee on Taxonomy of Viruses. Amsterdam, Netherlands: Elsevier Academic Press, s. 1139-62.

Alkowni R, Alabdallah O, Fadda Z (2019) Molecular identification of Tomato brown rugose fruit virus in tomato in Palestine. doi: https://doi.org/10.1007/s42161-019-00240-7.

Cambron-Crisantos JM, Rodríguez-Mendoza J, Valencia-Luna JB, Alcasio-Rangel S, García-Ávila CJ, López-Buenfil JA, OchoaMartínez DL (2018) First report of Tomato brown rugose fruit virus (ToBRFV) in Michoacan, Mexico. doi: https://doi.org/10.18781/R.MEX.FIT.1810-5.

Camacho-Beltrán E, Pérez-Villarreal A, Leyva-López NA (2019) Occurrence of Tomato brown rugose fruit virus infecting tomato crops in Mexico. doi: https://doi.org/10.1094/PDIS-11-18-1974PDN.

Chitambar J (2018) California pest rating for Tomato brown rugose fruit virus. https://blogs.cdfa.ca.gov/Section $3162 / ? \mathrm{p}=5843$. Erişim 12 Mart 2020. 
Dombrovsky A, Smith E (2017) Seed transmission of Tobamoviruses: Aspects of global disease distribution. In: Jimenez-Lopez JC, ed. Advances in Seed Biology. London, UK: IntechOpen, 233-60.

Domingo E, Holland JJ (1997) RNA virus mutations and fitness for survival. Annual Review of Microbiology 51: 151-78.

EPPO (2019) (European and Mediterranean Plant Protection Organization) https://gd.eppo.int/taxon/TOBRFV/distribution. Erişim 03 Mart 2020

FAO (2017) FAOSTAT. Food and Agriculture Organisation Data. [http://www.fao.org/faostat/en/]. Erişim 29 Aralık 2019.

Fidan H (2019) https://zkm.tarimorman.gov.tr/antalya/Haber/45/ Tomato-Brown-Rugose-Fruit-Virusu-Egitimi-Yapildi. Erișim 16 Mart 2020

Fidan H, Sarikaya P, Calis O (2019) First report of Tomato brown rugose fruit virus on tomato in Turkey. doi: http://dx.doi.org/10.5197/j.2044-0588.2019.039.018.

Fidan H, Sarkaya P (2020a) Yeni bir Tobamovirus: Tomato Brown Rugose Fruit Virus (ToBRFV) Leaflet. http://tohumculuk.akdeniz.edu.tr/. Erissim 12 Mart 2020.

Fidan H, Sarıkaya P (2020b) Antalya ili patlıcan (Solanum melongena) yetiştiriciliğinde sorun olan virüs hastalıkları. Mediterranean Agricultural Sciences 33(1): 27-35.

Gal-On A, Shiboleth YM (2006) Cross protection. In: Loebenstein G, Carr JP, eds. Natural Resistance Mechanisms of Plants to Viruses. Dordrecht, Netherlands: Kluwer Academic Publishers, 261-8.

Hamada H, Takeuchi, S, Morita, Y, Sawada, H., Kiba, A, Hikichi Y (2003) Characterization of Paprika mild mottle virus first isolated in Japan. Journal of General Plant Pathology 69(3): 199-204.

Hanssen IM, Mumford R, Blystad DR (2010) Seed transmission of Pepino mosaic virus in tomato. European Journal of Plant Pathology 126: 145-52.

Hanson P, Lu S, Wang JF, Chen W, Kenyon L, Tan CW, Kwee LT, Wang YY, Hsu YC, Schafleitner R, Ledesma D, Yang RY (2016) Conventional and molecular marker-assisted selection and pyramiding of genes for multiple disease resistance in tomato. Scientia Horticulturae 201: 346-54.

King AMQ, Adams MJ, Carstens EB, Lefkowitz EJ (2012) Ninth report of the international committee on taxonomy of viruses. San Diego, California USA: Elsevier Academic Press, pp. 486-487.

Lecoq H (1998) Control of plant virus diseases by cross protection. In: Hadidi A, Khetarpal RK, Koganezawa H, eds. Plant Virus Disease Control. (Chapter 3) St Paul, MN, USA: APS Press, pp. 33-40.

Levitzky N, Smith E, Lachman O, Luria N, Mizrahi Y, Bakelman H, Sela N, Laskar O, Milrot E, Dombrovsky A (2019) The bumblebee bombus terrestris carries a primary inoculum of Tomato brown rugose fruit virus contributing to disease spread in tomatoes. doi: https://doi.org/10.1371/journal.pone.0210871.

Liang C, Hao J, Li1 J, Baker B, Luo L (2019) Artificial microRNAmediated resistance to Cucumber green mottle mosaic virus in Nicotiana benthamiana. Planta 250: 1591-1601. https://doi.org/10.1007/s00425-019-03252-w.

Ling KS, Tian T, Gurung S, Gilliard A (2019) First report of Tomato brown rugose fruit virus infecting greenhouse tomato in the U.S. doi: https://doi.org/10.1094/PDIS-11-18-1959-PDN.
Luria N, Smith E, Reingold V, Bekelman I, Lapidot M, Levin I (2017) A new Israeli Tobamovirus isolate infects tomato plants harboring Tm-22 resistance genes. doi: 10.1371/journal.pone. 0170429.

Maayan Y, Pandaranayaka EPJ, Srivastava DA (2018) Using genomic analysis to identify tomato Tm-2 resistance breaking mutations and their underlying evolutionary path in a new and emerging Tobamovirus. Archives of Virology 163: 1863-75.

Mayer A, Johnson J, Ivanovskiı̌ DI, Beijerinck MW, Baur E (2009) UÈ ber die Mosaikkrankheit des Tabaks (in German), Concerning the mosaic disease of tobacco. Die Landwirtschaftliche Versuchsstationen 1942(32): 451-67.

Menzel W, Knierim D, Winter S, Hamacher J, Heupel M (2019) First report of Tomato brown rugose fruit virus infecting tomato in Germany. doi: http://dx.doi.org/10.5197/j.2044-0588.2019.039.001.

Moya A, Holmes EC, Gonzalez-Candelas F (2004) The population genetics and evolutionary epidemiology of RNA viruses. Nature Reviews Microbiology 2: 279-88.

Oladokun JO, Halabi MH, Barua P, Nath PD (2019) Tomato brown rugose fruit disease: Current distribution, knowledge and future prospects. Plant Pathology 68: 1579-1586.

Pai H, Jean W, Lee Y, Chang YA, Lin N (2019) Genome-wide analysis of small RNAs from Odontoglossum ringspot virus and Cymbidium mosaic virus synergistically infecting Phalaenopsis. Molecular Plant Pathology 21(2): 188-205.

Panno S, Garuso AG, Davino S (2019) Disease notes-First report of Tomato brown rugose fruit virus on tomato crops in Italy. doi: https://doi.org/10.1094/PDIS-12-18-2254-PDN.

Prins M, Laimer M, Noris E, Schubert J, Wasseneger M, Tepfer M (2008) Strategies for antiviral resistance in transgenic plants. Molecular Plant Pathology 9: 73-83.

Salem N, Mansour A, Ciuffo M, Falk BW, Turina M (2016) A new Tobamovirus infecting tomato crops in Jordan. Archives of Virology 161(2): 503-506.

Skelton A, Buxton-Kirk A, Ward R, Harju V, Frew L, Fowkes A, Long M, Negus A, Forde S, Adams IP, Pufal H, McGreig S, Weekes R, Fox A (2019) First report of Tomato brown rugose fruit virus in tomato in the United Kingdom. doi: http://dx.doi.org/10.5197/j.2044-0588.2019.040.012.

Tarım ve Orman Bakanlı̆̆ https://www.tarimorman.gov.tr/GKGM/Belgeler/Bitki\%20Sa\%C4 $\% 9 \mathrm{~F} 1 \% \mathrm{C} 4 \%$

\%C4\%9F\%C4\%B1\%20Hizmetleri/bitki_sagligi/survey/42

Tomato_brown_rugose_fruit_tobamovirus_(ToBRFV) (2019).pdf Erișim 12 Mart 2020.

Wetter C, Dore I, Bernard M (1987) Bell pepper mottle virus, a distinct Tobamovirus infecting pepper. Journal of Phytopathology 119(4): 333-344.

Yan Z, Ma HY, Han SL, Geng C, Tian YP, Li XD (2019) First report of Tomato brown rugose fruit virus infecting tomato in China. doi: 10.1094/PDIS-05-19-1045-PDN. 